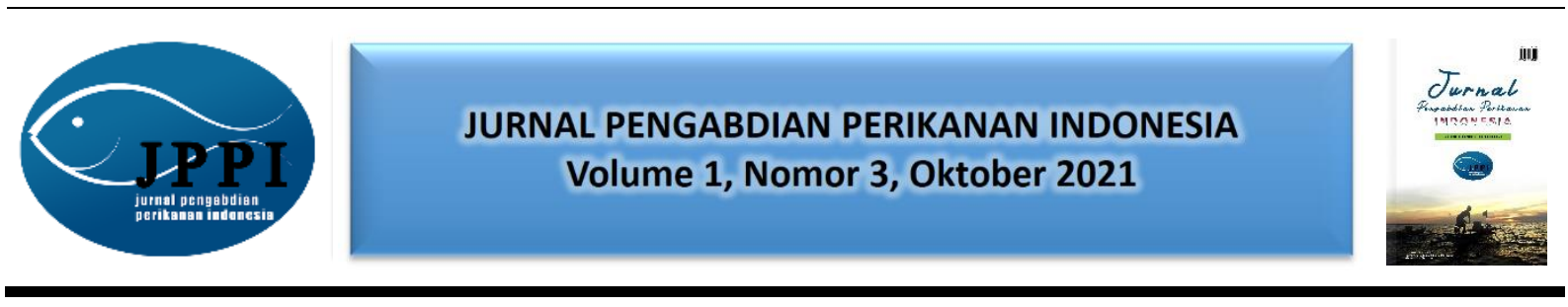

\title{
KEPADATAN DAN POLA SEBARAN RAJUNGAN Portunus pelagicus (Linnaeus, 1758) DI PERAIRAN PESISIR KECAMATAN BATU AMPAR, KABUPATEN KUBU RAYA
}

\section{Winda Eka Putri*, Tri Rima Setyawati, Diah Wulandari Rousdy}

Program Studi Biologi, Universitas Tanjungpura

*J. Prof. Dr. H. Hadari Nawawi, Kota Pontianak, Provinsi Kalimantan Barat

*Alamat korespondensi : windaekaputri@student.ac.id

(Tanggal Submission: : 9 September 2021, Tanggal Accepted : 31 Oktober 2021)

\begin{abstract}
Keyword: Abstrak:
rajungan, Rajungan (Portunus pelagicus) merupakan biota akuatik yang memiliki komoditas mangrove, ekonomi dan dimanfaatkan oleh masyarakat pesisir mangrove Kecamatan Batu Kecamatan Ampar, sehingga perlu mendapat pengawasan keberadaannya di alam. Tujuan Batu Ampar kegiatan pengabdian ini adalah mengetahui kepadatan, pola sebaran, dan mengetahui korelasi karakteristik habitat rajungan dengan kepadatan. Penelitian ini dilaksanakan selama bulan Desember 2019-Februari 2020. Pengambilan sampel dilakukan pada 3 stasiun penelitian menggunakan gill net berukuran 4 inchi. Data yang diperoleh kemudian dianalisis meliputi kepadatan dan pola sebaran. Korelasi karakteristik habitat dianalisis menggunakan Principal Component Analysis (PCA). Pengaruh stasiun dan waktu penangkapan dianalisis menggunakan Anova dua jalur. Kepadatan rajungan berkisar 222-2581 ind $/ \mathrm{km}^{2}$ dan berbeda selama bulan Desember-Februari. Pola Sebaran pada bulan Desember dan Januari termasuk seragam dan mengelompok, bulan Februari memiliki sebaran seragam dan acak. Stasiun penelitian tidak berpengaruh terhadap kepadatan rajungan, sedangkan waktu penelitian di Pesisir Batu Ampar memberikan pengaruh. Kepadatan populasi rajungan dan pola sebaran rajungan berkorelasi positif terhadap kedalaman, kecerahan, salinitas, $\mathrm{pH}$ air, kecepatan arus air, kecepatan angin, suhu air, $\mathrm{DO}$, dan $\mathrm{CO}_{2}$ bebas.
\end{abstract}

Panduan Sitasi (APPA $7^{\text {th }}$ edition) :

Putri, W. E., Setyawati, T. R., \& Rousdy, D. W. (2021). Kepadatan dan Pola Sebaran Rajungan (Portunus Pelagicus Linnaeus, 1758) di Perairan Pesisir Kecamatan Batu Ampar, Kabupaten Kubu Raya. Jurnal Pengabdian Perikanan Indonesia, 1 (3), 210-224. http://doi.org/ 10.29303/jppi.v1i3.343 


\section{PENDAHULUAN}

Ekosistem mangrove merupakan salah satu kawasan yang penting bagi biota akuatik yang hidup di sekitarnya. Ekosistem mangrove berada di sepanjang garis pantai kawasan tropis, dan memiliki peran ekologis seperti siklus hara dan habitat biota akuatik (Donato et al., 2012). Umumnya kawasan ini digunakan sebagai tempat mencari pakan, berlindung dari predator alaminya, dan pemijahan beberapa biota akuatik (Lee et al., 2014). Indonesia merupakan satu dari 105 negara yang memiliki mangrove terluas di dunia, yakni $20 \%$ diikuti oleh Brazil $11 \%$ dari total luas mangrove di dunia. Luas mangrove di Indonesia pada tahun 2017 diperkirakan 3,2 juta hektar (Tampubolon, 2017). Salah satu wilayah ekosistem mangrove di Indonesia yang memiliki manfaat ekologi dan ekonomi terdapat di Kecamatan Batu Ampar, Kabupaten Kubu Raya. Mangrove Batu Ampar adalah mangrove alami sebagai bagian wilayah peralihan antara ekosistem darat dan air payau. Mangrove Batu Ampar mencakup area seluas kurang lebih 14.050 ha dan berasal dari ekosistem Muara Sungai Kapuas (Hernowo, 2016).

Salah satu biota akuatik yang ditemukan di Perairan Barat Batu Ampar adalah kelompok krustasea dari Famili Portunidae. Rajungan (Portunus pelagicus) merupakan jenis yang paling umum ditemukan di Perairan Batu Ampar. Rajungan umumnya dimanfaatkan sebagai sumber makanan dan kosmetik (bagian karapas). Perannya dalam ekosistem mangrove juga sangat penting, yaitu mengkonversi nutrien, mempercepat mineralisasi, meningkatkan distribusi oksigen di dalam tanah, membantu siklus hara serta sebagai penyedia pakan alami untuk spesies biota akuatik lainnya. Anggota dari Famili Portunidae memiliki peran penting dalam rantai makanan di area estuari sebagai predator (scavenger) (Vorsatz, 2009).

Aktivitas penangkapan rajungan oleh nelayan telah menjadi mata pencaharian utama di Kecamatan Batu Ampar. Daerah penangkapan yang relatif semakin jauh dari pesisir, ukuran hasil tangkapan yang semakin kecil, dan penurunan produktivitas penangkapan yang terjadi berpotensi membuat nelayan menangkap rajungan yang tidak sesuai dengan Permen KP No. 1/2015, yaitu dalam kondisi bertelur dan lebar karapas $<10 \mathrm{~cm}$. Nilai ekonomi dari rajungan yang tinggi meningkatkan upaya penangkapan di alam sehingga dapat memicu terjadinya overfishing. Upaya budidaya rajungan juga telah dilakukan oleh Tanti \& Sulwartiwi (2010), namun dalam pemeliharaan kematian benih rajungan yang terjadi akibat kematian plankton, penyakit jamur merah, dan kanibalisme.

Permintaan pasar yang tinggi terhadap rajungan tidak diimbangi dengan upaya dalam memenuhi kebutuhan pasar, aktivitas penangkapan rajungan sangat bergantung pada tangkapan di alam. Keberadaan rajungan perlu mendapat perhatian atau upaya konservasi, salah satunya pengawasan terhadap populasi rajungan.

Perilaku rajungan dalam mempertahankan keberlangsungan populasinya melakukan migrasi rajungan yang membutuhkan habitat tertentu. Kajian mengenai kepadatan dan distribusi populasi rajungan biru (P. pelagicus) di Perairan Barat Kecamatan Batu Ampar perlu dilakukan. Kajian ini memberikan informasi dan memudahkan pemahaman mengenai sejumlah habitat penting yang perlu direncanakan bagi pengelolaan sumber daya berkelanjutan berbasis ekosistem.

\section{METODE KEGIATAN}

\section{Waktu dan Tempat}

Kegiatan ini dilaksanakan pada bulan Desember 2019-Februari 2020 yang bertempat di Perairan Pesisir Kecamatan Batu Ampar, Kabupaten Kubu Raya. Kecamatan Batu Ampar berjarak 77,5 km selatan dari Kota Pontianak (Gambar 1). Perairan di Kecamatan Batu Ampar, Kabupaten Kubu Raya 
merupakan mangrove alami dari muara Sungai Kapuas. Luas wilayah Kecamatan Batu Ampar adalah $2.002,70 \mathrm{~km}^{2}$ (28,67 \%) dari luas Kabupaten Kubu Raya, dengan luas hutan mangrove $\pm 140,5 \mathrm{~km}^{2}$. Bagian utara berbatasan dengan Kecamatan Kubu, Kabupaten Kubu Raya, sebelah timur berbatasan dengan Kabupaten Sanggau, sebelah selatan berbatasan dengan Kabupaten Ketapang, dan sebelah barat berbatasan dengan Selat Karimata. Nelayan di lokasi ini termasuk nelayan harian (one day fishing) (BPS, 2020).
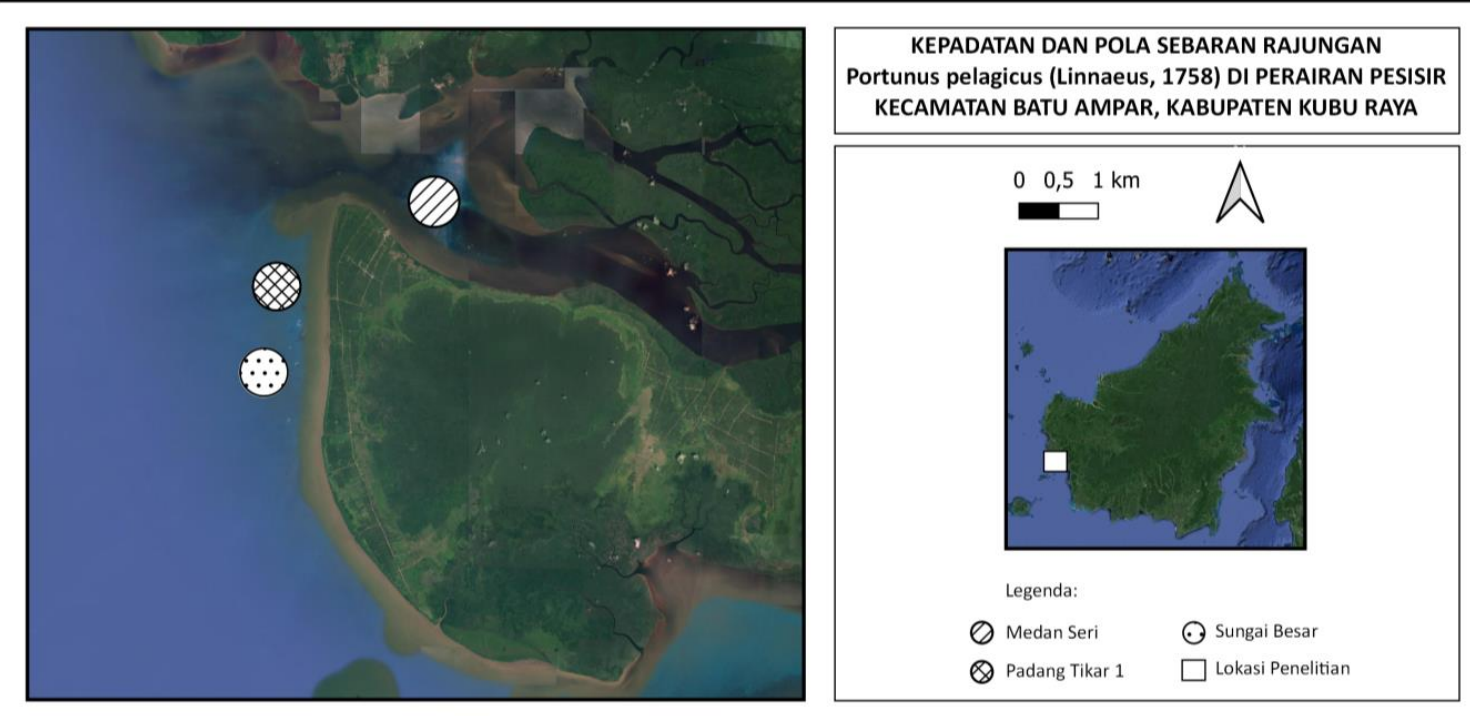

Gambar 1. Peta Lokasi Penelitian

Berdasarkan hasil survei yang dilakukan diketahui terdapat 3 rona lingkungan yang berbeda berdasarkan karakteristik morfologi dan vegetasi pantai di Pesisir Batu Ampar. Adapun deskripsi dari masing-masing rona tersebut terlihat pada Tabel 1.

Tabel 1. Deskripsi Rona Lingkungan

\begin{tabular}{|c|c|}
\hline Stasiun & Rona Lingkungan \\
\hline Medan Seri & $\begin{array}{l}\text { Pesisir Teluk Bengkolan, pantai landai, ada pengaruh arus dari teluk, } \\
\text { substrat dominan pasir berlumpur, vegetasi didominasi tumbuhan } \\
\text { Avicennia sp., terdapat dermaga masyarakat. }\end{array}$ \\
\hline Padang Tikar 1 & $\begin{array}{l}\text { Pantai landai, substrat dominan lumpur, vegetasi mangrove jarang, } \\
\text { terdapat pemukiman dan dermaga. }\end{array}$ \\
\hline Sungai Besar & $\begin{array}{l}\text { Pantai landai, substrat berlumpur, vegetasi mangrove rapat, pemukiman } \\
\text { warga jarang. }\end{array}$ \\
\hline
\end{tabular}

\section{Pengambilan Sampel}

Penentuan titik pengambilan sampel menggunakan metode random sampling didasarkan pada hasil wawancara dari nelayan mengenai lokasi yang menjadi daerah penangkapan rajungan. Setiap stasiun penelitian terdiri dari 2 titik pengambilan sampel. Pengambilan sampel rajungan pada masing-masing titik sampling menggunakan alat tangkap pukat (gill net) bersifat benthic gear (alat tangkap dasar) ukuran mata jaring 4 inchi $(10.16 \mathrm{~cm}$ ) dengan panjang dan lebar $487.6 \mathrm{~m} \mathrm{X} 1.2 \mathrm{~m}$. Rajungan yang ditangkap dipisahkan antara kelompok jantan dan betina. Kriteria jenis kelamin 
didasarkan bentuk abdomen, betina memiliki bentuk abdomen tumpul, sedangkan jantan memiliki abdomen meruncing (Nugraheni et al.,, 2015). Setiap rajungan dalam masing-masing kelompok tersebut kemudian dihitung jumlah individu, diukur lebar dan panjang karapas. Pengukuran parameter lingkungan dilakukan di setiap titik pengambilan sampel (Tabel 2).

Tabel 2. Parameter Lingkungan Perairan yang Diukur

\begin{tabular}{lll}
\hline \multicolumn{1}{c}{ Parameter } & \multicolumn{1}{c}{ Teknik Pengukuran } & Keterangan \\
\hline Kedalaman $(\mathrm{m})$ & Depth finder & In-situ \\
Kecerahan $(\mathrm{m})$ & Secchi disk & In-situ \\
Salinitas \%o & Refraktometer & In-situ \\
Kecepatan arus air $(\mathrm{m} / \mathrm{s})$ & Flow meter & In-situ \\
Suhu air $\left({ }^{\circ} \mathrm{C}\right)$ & Termometer Hg & In-situ \\
Dissolved Oxygen $(\mathrm{mg} / \mathrm{L})$ & Winkler & In-situ \\
$\mathrm{CO}_{2}$ bebas & Winkler & In-situ \\
Tipe tesktur & Saringan bertingkat & Laboratorium \\
\hline
\end{tabular}

\section{Analisis Data}

\section{Kepadatan Populasi}

Kepadatan populasi rajungan dinyatakan dengan satuan individu per kilometer persegi. Luas gill net yang digunakan pada saat pengambilan sampel adalah $0.12 \mathrm{~km}^{2}$ dan dihitung menggunakan rumus berikut ini:

$$
\text { Kepadatan }(\text { ind } / \mathrm{km})=\frac{\text { Jumlah } \text { individu }}{\text { Luas gill net }}
$$

Analisis kepadatan populasi antar stasiun dilakukan dengan cara membandingkan ada atau tidaknya pengaruh stasiun dan bulan terhadap kepadatan rajungan. Analisis yang digunakan adalah Analysis of Variance (Anova) dua jalur. Aplikasi yang digunakan adalah R Studio versi 4.0.1.

\section{Pola Sebaran}

Pola sebaran dilakukan analisis dengan memetakan distribusi rajungan yang ditemukan di lapangan pada setiap stasiun pengambilan sampel. Penentuan pola sebaran jenis dari suatu organisme pada habitatnya dapat ditentukan dengan menggunakan Indeks Dispersi Morisita (Iठ) (Krebs, 2014). Rumus untuk menghitung Indeks Sebaran Morisita sebagai berikut:

$$
\mathrm{I} \delta=n\left(\frac{\sum X^{2}-\sum X}{\left(\sum X\right)^{2}-\sum X}\right)
$$

Keterangan:

I $=$ = Indeks Dispersi Morisita

$n \quad=$ Jumlah stasiun pengambilan contoh

$\Sigma X \quad$ = Jumlah individu yang ditemukan pada setiap plot $=\mathrm{x}^{1}+\mathrm{x}^{2}+\mathrm{x}^{3}+\ldots$

$\sum X^{2}=$ Jumlah individu yang ditemukan pada setiap plot $=\left(x^{1}\right)^{2}+\left(x^{2}\right)^{2}+\left(x^{3}\right)^{3}+\ldots$

Indeks Dispersi Morisita kemudian dihitung indeks kehomogenan penyebaran dengan persamaan berikut (Metananda et a., 2016): 
Uniform Indexs $=\mathrm{Mu}=\frac{X^{2} 0,975-n+\sum X}{\left(\sum X\right)-1} \quad$ Clumped Indexs $=\mathrm{Mc}=\frac{X^{2} 0,025-n+\sum X}{\left(\sum X\right)-1}$

Keterangan:

$X^{2}{ }_{0,975}=$ Nilai dari tabel dengan $\mathrm{df}(\mathrm{n}-1)$ dengan taraf kepercayaan $97,5 \%$

$X^{2}{ }_{0,025}=$ Nilai dari tabel dengan $\mathrm{df}(\mathrm{n}-1)$ dengan taraf kepercayaan $2,5 \%$

$\Sigma X \quad=$ Jumlah individu yang ditemukan pada setiap plot $=\mathrm{x}^{1}+\mathrm{x}^{2}+\mathrm{x}^{3}+\ldots$

$\mathrm{n} \quad=$ Jumlah stasiun pengambilan contoh

Hasil indeks kehomogenan penyebaran kemudian dihitung berdasarkan salah satu dari empat persamaan berikut ini (Metananda et al., 2016):
1. Jika $I \delta \geq M c>1$
$: I_{p}=0,5+0,5\left(\frac{I \delta-M c}{n-M c}\right)$
3. Jika $1>\mathrm{I} \delta>\mathrm{Mu}$
$: I_{p}=-0,5\left(\frac{I \delta-1}{M u-1}\right)$
2. Jika $M c>I \delta \geq 0$
$: I_{p}=0,5\left(\frac{I \delta-1}{M u-1}\right)$
4. Jika $1>\mathrm{Mu}>\mathrm{I} \delta$
$: I_{p}=-0,5+0,5\left(\frac{I \delta-M u}{M u}\right)$

Hasil perhitungan Indeks Sebaran Morisita dibandingkan dengan kriteria sebagai berikut:

$\mathrm{I}_{\mathrm{p}}<0$ : Pola sebaran individu jenis bersifat seragam

$I_{p}=0:$ Pola sebaran individu jenis bersifat acak

$I_{p}>0$ : Pola sebaran individu jenis bersifat kelompok

\section{Korelasi Parameter Lingkungan}

Korelasi parameter lingkungan terhadap kepadatan dan pola sebaran rajungan (Portunus pelagicus) dianalisis dengan pendekatan statistik multivariat yang menggunakan Analisis Komponen Utama/Principal Component Analysis (PCA). Perangkat lunak yang digunakan untuk analisis PCA adalah Past3 (Paleontological Statistics) versi 3.26.

\section{HASIL DAN PEMBAHASAN}

\section{Kepadatan dan Pola Sebaran Rajungan (Portunus pelagicus) di Perairan Batu Ampar}

Jumlah individu rajungan ( $P$. pelagicus) di Perairan Batu Ampar pada 3 stasiun selama bulan Desember 2019-Februari 2020 (Gambar 2) diperoleh 1030 individu dengan 586 individu jantan dan 444 individu betina. Hasil rajungan yang terjaring tertinggi berada di Stasiun Padang Tikar 1 bulan Desember diperoleh 302 individu dengan 240 individu jantan dan 62 individu betina. Hasil tangkapan terendah berada pada Stasiun Padang Tikar 1 bulan Februari diperoleh 26 individu dengan 18 individu jantan dan 8 individu betina. 


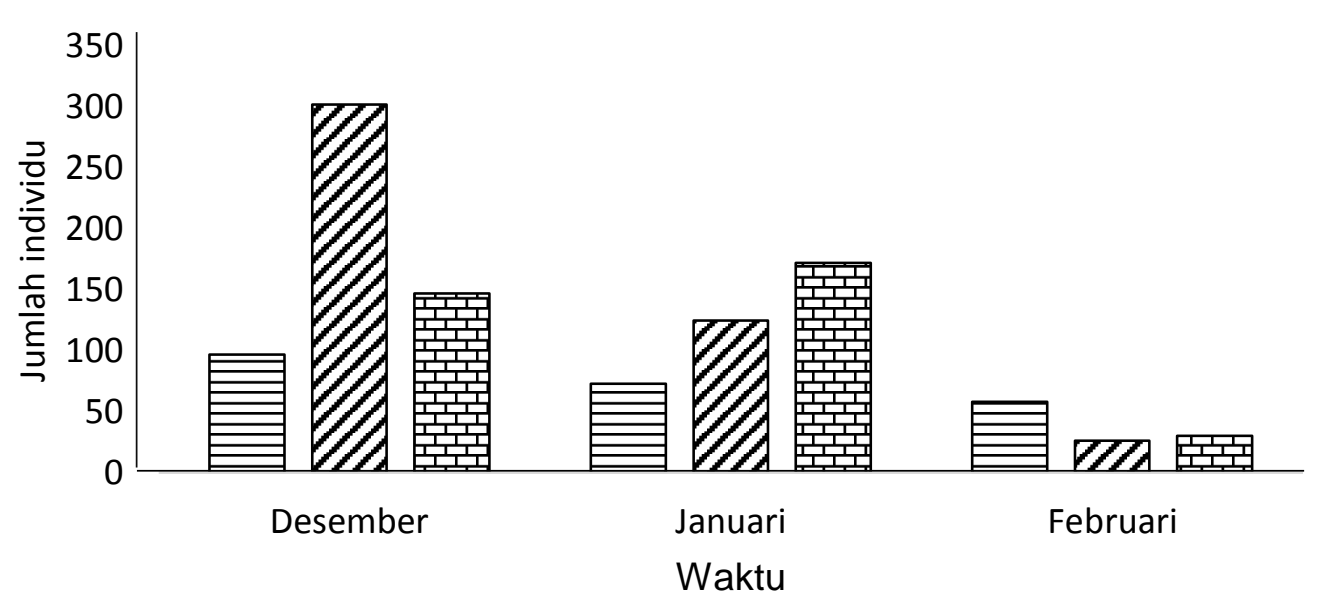

Gambar 2. Jumlah individu rajungan ( $P$. pelagicus) pada setiap stasiun selama bulan DesemberFebruari. Keterangan : Stasiun, $M$ Medan seri, $\mathscr{Z}$ Padang Tikar 1,

Ukuran rajungan yang diperoleh berdasarkan lebar karapasnya dikelompokkan menjadi tiga, yaitu $<6 \mathrm{~cm}$ (anakan) sebanyak 0 individu , 6-12 cm (rajungan remaja) sebanyak 579 individu, dan $>12$ cm (rajungan dewasa) 451 individu. Secara umum sebaran jumlah individu terbanyak berdasarkan lebar karapas baik rajungan jantan maupun betina berada pada ukuran 6-12 cm (Gambar 3).

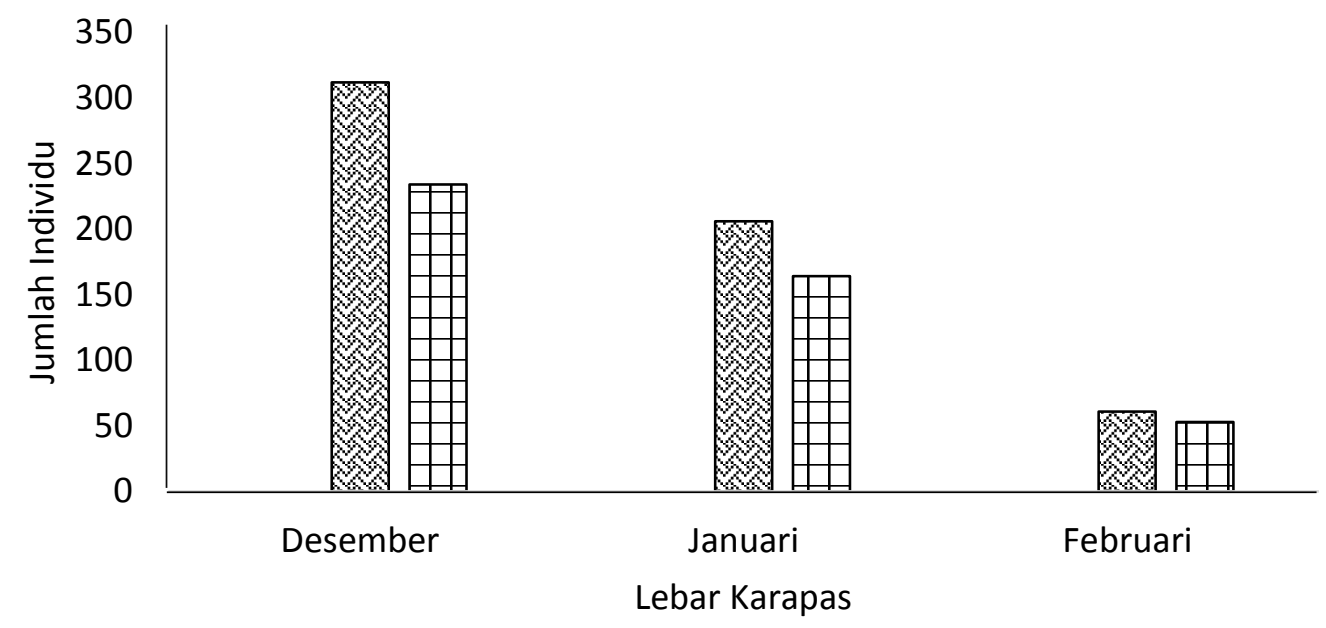

Gambar 3. Jumlah individu berdasarkan lebar karapas rajungan ( $P$. pelagicus) di Perairan Batu Ampar pada bulan Desember 2019-Februari 2020

Keterangan: Ukuran karapas, 6-12 cm,

Rajungan ( $P$. pelagicus) di Perairan Batu Ampar memiliki kepadatan yang berbeda pada setiap lokasi dan waktu pengambilan (Tabel 1 ). Luas gill net yang digunakan pada saat pengambilan sampel adalah $0.12 \mathrm{~km}^{2}$. Kepadatan rata-rata 3 stasiun sebesar 978 individu/ $\mathrm{km}^{2}$ (jantan 556 individu $/ \mathrm{km}^{2}$ dan betina 422 individu $/ \mathrm{km}^{2}$ ).

Kepadatan rajungan tertinggi di bulan Desember berada pada Stasiun Padang Tikar, 1 yaitu 2581 individu/ $/ \mathrm{km}^{2}$. Kepadatan terendah pada Stasiun Medan Seri, yaitu 829 individu/km². Kepadatan rajungan tertinggi di bulan Januari tertinggi terdapat pada Stasiun Sungai Besar dengan 1470 individu $/ \mathrm{km}^{2}$. Kepadatan terendah pada Stasiun Medan Seri, yaitu 624 individu/ $\mathrm{km}^{2}$. Kepadatan 
rajungan teringgi di bulan Februari terdapat pada Stasiun Medan Seri, yaitu 496 individu/km². Kepadatan terendah pada Stasiun Padang Tikar 1, yaitu 222 individu $/ \mathrm{km}^{2}$ (Tabel 3).

Tabel 3. Kepadatan dan Pola Sebaran Rajungan (P. pelagicus) di Perairan Batu Ampar

\begin{tabular}{clcccl}
\hline Waktu & \multicolumn{1}{c}{ Stasiun } & $\mathbf{K}\left(\mathbf{i n d} / \mathbf{k m}^{\mathbf{2}}\right)$ & $\mathbf{I} \mathbf{\delta}$ & $\mathbf{I} \mathbf{P}$ & Pola Sebaran \\
\hline \multirow{3}{*}{ Desember } & Medan Seri & 829 & 0,18 & $-0,91$ & Seragam \\
& Padang Tikar 1 & 2581 & 1,83 & 0,06 & Kelompok \\
& Sungai Besar & 1256 & 0,42 & $-0,79$ & Seragam \\
\multirow{3}{*}{ Januari } & Medan Seri & 624 & 0,22 & $-0,89$ & Seragam \\
& Padang Tikar 1 & 1068 & 0,67 & $-0,66$ & Seragam \\
& Sungai Besar & 1470 & 1,28 & 0,01 & Kelompok \\
\multirow{3}{*}{ Februari } & Medan Seri & 496 & 1,51 & 0,00 & Acak \\
& Padang Tikar 1 & 222 & 0,26 & $-0,87$ & Seragam \\
& Sungai Besar & 256 & 0,37 & $-0,81$ & Seragam \\
\hline
\end{tabular}

Keterangan $\quad: K=$ Kepadatan; $I \delta=$ Indeks Dispersi Morisita; $I_{\mathrm{p}}=$ Indeks Morisita yang distandarisasi

Pola sebaran rajungan ( $P$. pelagicus) di Perairan Batu Ampar berdasarkan nilai Indeks Dispersi Morisita (I $\delta$ ) pada Tabel 3 dengan hasil berkisar 0,18-1,83. Perhitungan nilai Indeks Dispersi Morisita (Iठ) menunjukkan pola yang berbeda menurut stasiun dan waktu penangkapan.

Bulan Desember menunjukkan pola seragam pada stasiun Medan Seri dan Sungai Besar, pola mengelompok di stasiun Padang Tikar 1. Bulan Januari menunjukkan pola seragam pada stasiun Medan Seri dan Padang Tikar 1, stasiun Sungai Besar menunjukkan pola mengelompok. Bulan Februari menunjukkan pola seragam pada stasiun Padang Tikar 1 dan Sungai Besar, pola acak stasiun Medan Seri.

Tabel 4. Hasil Uji Anova Kepadatan Rajungan (P. pelagicus) di Perairan Batu Ampar

\begin{tabular}{lccccc}
\hline & Df & Sum Sq & Mean Sq & F Value & Pr $(>\mathbf{F})$ \\
\hline Bulan & 2 & 1,238 & 0,6190 & 6,488 & $0,0111^{*}$ \\
Stasiun & 2 & 0,083 & 0,0415 & 0,435 & 0,6565 \\
Residuals & 13 & 1,240 & 0,0954 & & \\
\hline
\end{tabular}

Hasil perhitungan Anova (Tabel 4) diperoleh hasil probabilitas ( $p>f)$ bulan 0,01<0,05 dan stasiun sebesar $0,6>0,05$. Dengan demikian perbedaan waktu penangkapan memberikan pengaruh kepadatan populasi rajungan dan stasiun tidak memberikan pengaruh.

\section{Karakteristik Habitat Rajungan (Portunus pelagicus) di Perairan Batu Ampar}

Karakteristik habitat di Perairan Batu Ampar dilakukan pengamatan pada setiap bulan pengambilan sampel untuk masing-masing stasiun (Tabel 5). Faktor lingkungan yang diamati diolah dengan deskriptif dan statistik dengan metode Principal Component Analysis (PCA) meliputi kedalaman $(m)$, kecerahan $(m)$, salinitas $(\%)$, pH air, kecepatan arus air $(m / s)$, suhu air $\left({ }^{\circ} \mathrm{C}\right), D O(m g / L)$, dan $\mathrm{CO}_{2}$ bebas $(\mathrm{mg} / \mathrm{L})$. Faktor lingkungan tekstur substrat diolah dengan metode deskriptif.

Tabel 5. Hasil Pengukuran Faktor Lingkungan di Perairan Batu Ampar 


\begin{tabular}{|c|c|c|c|c|}
\hline \multicolumn{2}{|c|}{ Parameter Lingkungan } & Medan Seri & Padang Tikar 1 & Sungai Besar \\
\hline \multicolumn{2}{|c|}{ Kedalaman (m) } & $4,37^{*}$ & $5,32^{* *}$ & 5,03 \\
\hline \multicolumn{2}{|c|}{ Kecerahan (m) } & $0,78^{*}$ & $1,28^{* *}$ & 1,25 \\
\hline \multicolumn{2}{|c|}{ Salinitas (\%o) } & $27,17^{*}$ & 28,17 & $28,50^{* *}$ \\
\hline \multicolumn{2}{|l|}{$\mathrm{pH}$ air } & $8,46^{*}$ & 8,57 & $8,75^{* *}$ \\
\hline \multicolumn{2}{|c|}{ Kecepatan Arus Air (m/s) } & $0,72^{*}$ & 1,10 & 1,10 \\
\hline \multicolumn{2}{|l|}{ Suhu Air $\left({ }^{\circ} \mathrm{C}\right)$} & $29^{* *}$ & $28^{*}$ & 28 \\
\hline \multicolumn{2}{|c|}{ DO Terlarut (mg/L) } & $1,66^{*}$ & 1,86 & $2,05^{* *}$ \\
\hline \multicolumn{2}{|c|}{$\mathrm{CO}_{2}$ Bebas $(\mathrm{mg} / \mathrm{L})$} & $3,93^{*}$ & 4,00 & $4,21^{* *}$ \\
\hline \multirow{3}{*}{$\begin{array}{l}\text { Tekstur } \\
\text { Substrat (\%) }\end{array}$} & Debu & $56,21^{*}$ & 58,24 & $70,82^{* *}$ \\
\hline & Pasir & $38,59^{* *}$ & $16,32^{*}$ & 23,98 \\
\hline & Liat & 5,20 & $25,44^{* *}$ & 5,20 \\
\hline
\end{tabular}

Keterangan $:{ }^{*}=$ terendah $;{ }^{* *}=$ tertinggi

Pengukuran faktor lingkungan terhadap kepadatan dan pola sebaran rajungan ( $P$. pelagicus) diuji menggunakan Analisis Komponen Utama/Principal Component Analysis (PCA). Korelasi parameter lingkungan dengan keberadaan populasi $P$. pelagicus disajikan pada Gambar 4.4. Berdasarkan diagram, sebaran faktor lingkungan berbeda-beda pada setiap stasiun pengambilan. Perbedaan ini menunjukkan bahwa keberadaan populasi $P$. pelagicus dipengaruhi oleh faktor lingkungan.

Tabel 6. Hasil Perhitungan Principal Component Analysis (PCA)

\begin{tabular}{ccc}
\hline$P C$ & Eigenvalue & \% variance \\
\hline 1 & 5,36534 & 59,615 \\
2 & 2,03134 & 22,57 \\
3 & 0,779448 & 8,6605 \\
4 & 0.548546 & 6,095 \\
5 & 0.27533 & 3,0592 \\
\hline
\end{tabular}

Diagram sebar (Gambar 2) menunjukkan parameter lingkungan yang berpengaruh pada stasiun pengambilan sampel. Stasiun Medan Seri dicirikan oleh parameter suhu air, $\mathrm{CO}_{2}$ bebas. Stasiun Sungai Besar dicirikan oleh parameter $\mathrm{CO}_{2}$ bebas, $\mathrm{pH}$ air, $\mathrm{O}_{2}$ terlarut, dan salinitas. Kecepatan arus air, kecerahan, kedalaman, dan kecepatan angin mempengaruhi Stasiun Padang Tikar. Parameter lingkungan penciri tersebut merupakan parameter penciri yang memengaruhi keberadaan rajungan pada setiap stasiun. 


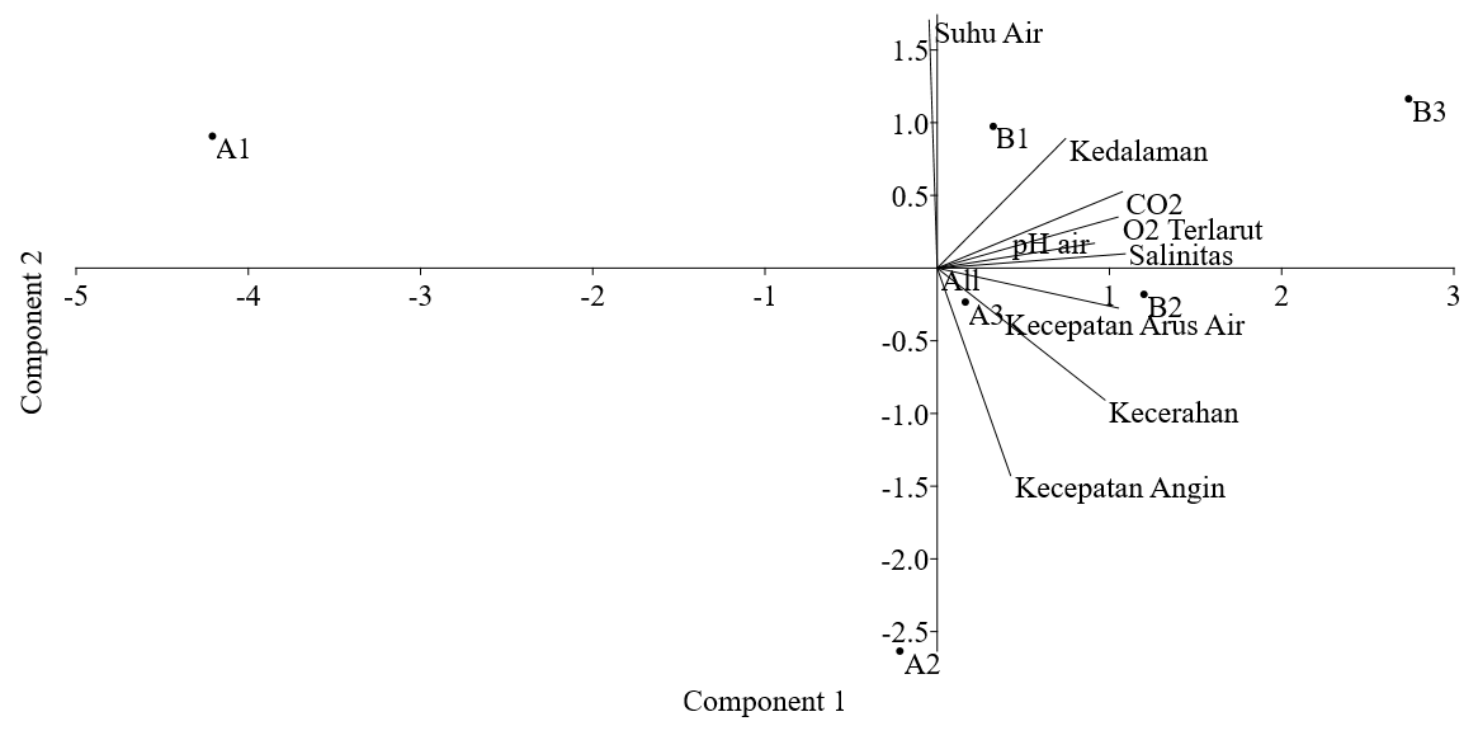

Gambar 4. Diagram sebar korelasi antara stasiun pengambilan dengan parameter lingkungan Keterangan: (A1,B1=Medan Seri, A2,B2=Padang Tikar, A3,B3=Sungai Besar)

\section{Pembahasan}

Kepadatan rajungan yang ditangkap umumnya berbeda di setiap stasiun selama bulan Desember-Februari. Kepadatan tertinggi ditemukan pada bulan Desember di stasiun Padang Tikar. Hal ini dikarenakan pada saat penangkapan rajungan, spesies non target (ikan pari, udang ronggeng) terjaring. Keberadaan spesies non target pada jaring menjadi salah satu pakan, sehingga rajungan yang tertangkap lebih banyak. Rajungan merupakan karnivora yang memangsa hewan segar sebagai pakan. Hasil penelitian Neilirrohmah et al., (2019) menunjukkan bahwa rajungan lebih banyak tertangkap dengan umpan segar dibandingkan dengan umpan limbah udang. Aroma ikan segar lebih menyengat, menyebabkan rajungan lebih tertarik pada umpan segar.

Kepadatan rajungan juga dipengaruhi oleh siklus bulan pengambilan sampel. Pengambilan sampel pada bulan Desember berada pada siklus bulan baru sedangkan bulan Januari dan Februari dilakukan berada pada kondisi bulan purnama. Wiyono \& Ihsan (2015) menyatakan bahwa siklus bulan memengaruhi proses maturasi, molting, dan reproduksi pada anggota Krustasea Ordo Decapoda, sehingga memengaruhi hasil tangkapan rajungan. Penelitian ini menemukan bahwa jumlah individu terbanyak ditangkap berada saat bulan Desember, yaitu pada siklus bulan baru. Hal ini sesuai dengan penelitian Hamsa (1978) dan Wiyono \& Ihsan (2015) yang mencatat bahwa jumlah tangkapan rajungan relatif banyak saat siklus bulan baru.

Perbedaan kepadatan rajungan juga dipengaruhi kondisi perairan, hal ini dikarenakan pada stasiun Padang Tikar memiliki kedalaman $>5 \mathrm{~m}$. Penelitan Mawaluddin et al., (2016); Nugraheni et al., (2015); Radifa et al., (2020) menyatakan bahwa rajungan dewasa umumnya semakin menjauhi dan menuju lepas pantai. Lokasi pengamatan dengan stratifikasi kedalaman 0-3 km dan 3-6 km tidak ditemukan rajungan dengan lebar karapas $>10 \mathrm{~cm}$. Rajungan dengan ukuran $>10 \mathrm{~cm}$ baru ditemukan pada kedalaman 6-10 km. Zairion et al., (2015) menyimpulkan bahwa rajungan betina dapat bertelur dan melakukan pemijahan pada kedalaman perairan $<5 \mathrm{~m}$ hingga $>10 \mathrm{~m}$, sehingga rajungan dapat ditemukan di seluruh kedalaman. 
Waktu penangkapan berdasarkan hasil perhitungan Anova menunjukkan adanya pengaruh terhadap kepadatan populasi rajungan. Pengambilan sampel pada bulan Desember, gill net memiliki waktu terendam rata-rata selama \pm 24 jam, sedangkan pada bulan Januari dan Februari waktu terendam berkisar 3-6 jam. Penelitian Suy (2013) menyatakan dalam satu kali perjalanan, pukat yang terendam selama 10 jam dapat menangkap kepiting dengan rata-rata berat $9.2 \mathrm{~kg}$. Sedangkan pukat yang terendam selama 5 jam menangkap rata-rata 5,1 kg. Hasil yang signifikan dapat diperoleh jika variasi waktu perendaman pukat dilakukan sangat lama atau sangat pendek (Smith et al., 1999)

Ukuran rajungan yang diperoleh di Perairan Batu Ampar berkisar 7-17 cm. Berdasarkan sebaran ukuran lebar karapas rajungan yang tertangkap di perairan ini lebih didominasi rajungan remaja $(6-12 \mathrm{~cm})$ dibandingkan rajungan dewasa $(>12 \mathrm{~cm})$. Dominasi keberadaan rajungan remaja terjadi baik pada bulan Desember, Januari, dan Februari. Hal ini karena area penangkapan yang digunakan merupakan perairan estuaria dangkal. Jose (2015) menemukan bahwa lambung rajungan remaja dan sub-dewasa didominasi oleh potongan daging dan tumbuhan. Erlinda et al., (2016) menyatakan bahwa komposisi pakan alami rajungan di Perairan Lakara, Konawe, Sulawesi Tenggara adalah plankton, daging ikan, moluska, dan material tidak teridentifikasi. Pakan alami untuk jantan dan betina juga tidak memiliki perbedaan secara spesifik. Chande \& Mgaya (2004), menyatakan bahwa tidak ada perbedaan nyata terhadap jenis pakan dari rajungan berdasarkan musim, jenis kelamin, ukuran kelas, dan rajungan betina mengerami telur (ovigerous dan non-ovigerous).

Kisaran ukuran yang diperoleh tidak berbeda jauh dengan penelitian di Perairan Kota Baru, Kalimantan Selatan, yaitu 8,5-18 cm dan di Perairan Kepulauan Aru berkisar 8-18 cm (Kembaren \& Adi, 2018; Tirtadanu \& Suman, 2017). Hasil penelitian Mawaluddin et al., (2016) menemukan bahwa komposisi ukuran lebar karapaks pada rajungan betina hasil tangkapan didominasi rajungan remaja. Perbedaan ukuran rajungan yang ditangkap dapat disebabkan jenis alat tangkap. Pengambilan sampel pada penelitian ini menggunakan alat tangkap jaring insang (gill net). Bambang et al., (2011) menyatakan bahwa umumnya ukuran rajungan yang ditangkap menggunakan gill net lebih besar daripada jaring sero. Rajungan yang diperoleh menggunakan gill net di Perairan Kien Giang, Vietnam lebih besar daripada menggunakan perangkap bubu (Ha et al., 2015).

Sebaran rajungan berdasarkan ukuran karapas berkaitan dengan kemampuan renang. Semakin besar ukuran semakin dapat mentoleransi gelombang yang kuat di perairan yang dalam. Perilaku migrasi pada musim pemijahan, betina yang mengerami telur (ovigerous) akan berenang menuju perairan yang lebih dalam dan berpengaruh terhadap sebaran rajungan (Chande \& Mgaya, 2004).

Pola sebaran pada bulan Desember di stasiun Padang Tikar 1 termasuk kategori mengelompok. Hal ini dikarenakan pukat diletakkan pada perairan dengan kedalaman $\pm 9 \mathrm{~m}$ dari permukaan air. Penelitan Mawaluddin et al. (2016); Nugraheni et al. (2015); Radifa et al. (2020) menyatakan bahwa rajungan dewasa umumnya semakin menjauhi dan menuju lepas pantai. Lokasi pengamatan dengan stratifikasi kedalaman 0-3 km dan 3-6 km tidak ditemukan rajungan dengan lebar karapas $>10 \mathrm{~cm}$. Rajungan dengan ukuran $>10 \mathrm{~cm}$ baru ditemukan pada kedalaman 6-10 km. Zairion et al. (2015) menyimpulkan bahwa rajungan betina dapat bertelur dan melakukan pemijahan pada kedalaman perairan $<5 \mathrm{~m}$ hingga $>10 \mathrm{~m}$, sehingga rajungan dapat ditemukan di seluruh kedalaman.

Karakteristik habitat rajungan di Perairan Batu Ampar pada semua stasiun penangkapan cenderung landai dengan kondisi substrat didominasi oleh fraksi debu, diikuti oleh fraksi pasir, dan fraksi liat. Hasil analisis tipe substrat yang hampir sama di seluruh stasiun disebabkan karena lokasi pengambilan sampel cenderung homogen. Perairan Batu Ampar memiliki karakteristik habitat 
kawasan mangrove. Kedalaman lokasi peletakkan pukat berkisar 2,8-9,1 m dari permukaan air laut. Menurut Rahimah et al., (2019) rajungan dapat ditemukan dari permukaan laut $\pm 1 \mathrm{~m}$ hingga kedalaman $65 \mathrm{~m}$.

Hasil pengamatan salinitas yang diperoleh di seluruh stasiun berkisar 27-28\%. Nilai salinitas tergolong rendah namun masih dalam toleransi untuk pertumbuhan rajungan remaja. Menurut Chande \& Mgaya (2004), rajungan memiliki toleransi salinitas berkisar 9-39\%. Rendahnya nilai salinitas di area penelitian disebabkan karena letak perairan ini merupakan muara dari Sungai Kapuas sehingga mendapatkan masukkan air tawar. Penelitian Salim et al. (2017) menemukan bahawa salinitas di Perairan Pulau Kerumputan, Kabupaten Kotabaru, Kalimantan Selatan berkisar 28-29\%o. Perairan Pulau Kerumputan juga mendapatkan masukkan air tawar dari beberapa sungai.

Kondisi pH pada Perairan Batu Ampar berkisar antara 8,46-8,74, kondisi ini menunjukkan bahwa pada stasisun penelitian masih sesuai dengan peraturan Kementerian Lingkungan Hidup Nomor 51 tahun 2004, yaitu 6,5-8,5. Nilai pH di stasiun penangkapan menunjukkan nilai yang hampir sama. Penelitian Schaduw (2018) di perairan ekosistem mangrove Pulau Kecil Taman Nasional Bunaken menunjukkan $\mathrm{pH} 8,07-8,20$ dan rata-rata $\mathrm{pH}$ pada pulau-pulau kecil Kabupaten Nunukan, Kalimantan Utara adalah 7,43-7,95 (Mustikasari et al., 2019).

Kecepatan arus di stasiun Padang Tikar dan Sungai Besar $(1,10 \mathrm{~m} / \mathrm{s})$ lebih besar dibandingkan dengan Stasiun Medan Seri $(0,70 \mathrm{~m} / \mathrm{s})$. Hal ini dikarenakan stasiun Padang Tikar dan Sungai Besar berada di Laut Natuna yang merupakan perairan terbuka, sedangkan Stasiun Medan Seri berada di Teluk Bengkolan. Perbedaan geografis tersebut menyebabkan perbedaan nilai kecepatan arus air (Wisha et al., 2015). Menurut Lino (2013) jumlah tangkapan rajungan dipengaruhi arus yang lambat, karena aroma dari tangkapan lain (non targeted species) lebih mudah dideteksi oleh rajungan. Rajungan diketahui bahwa menggunakan indera penciuman untuk memperoleh pakan. Penelitian Qadhafi et al. (2013) menyatakan hasil tangkapan menggunakan gill net dipengaruhi oleh kecepatan arus. Kecepatan arus tertinggi berada di Stasiun Padang Tikar dan Sungai Besar, hal ini menyebabkan kepadatan di stasiun ini lebih tinggi dari pada kepadatan di Stasiun Medan Seri.

Suhu di Perairan Batu Ampar berkisar antara $28-29^{\circ} \mathrm{C}$. Nilai suhu yang stabil menyebabkan ukuran rajungan yang diperoleh lebih seragam. Secara umum sebaran jumlah individu berdasarkan lebar karapas tertinggi baik jantan maupun betina berada pada ukuran 6-12 cm. Kisaran suhu ini menurut Santoso et al. (2016) masih sangat layak untuk kehidupan rajungan. Keberadaan organisme dapat dipengaruhi oleh suhu perairan. Suhu berperan dalam menentukan letak organisme di laut. Keseragaman ukuran pertumbuhan rajungan dapat dipengaruhi oleh suhu. (Castro \& Huber, 2016). Kestabilan suhu optimum pada setiap tahap kehidupan dapat memengaruhi tingkat keberhasilan kelulusan hidup rajungan. Kisaran suhu yang tinggi menyebabkan interval ekdisis terjadi lebih cepat (Juwana, 1997). Reaksi metabolisme semakin cepat saat suhu naik dan melambat saat suhu semakin dingin. Perubahan suhu secara ekstrim dapat membuat fungsi enzim terganggu (Castro \& Huber, 2016).

Oksigen terlarut yang diperoleh berkisar $1,26-2,50 \mathrm{mg} / \mathrm{L}$, kisaran nilai ini termasuk konsentrasi minimal. Wilson (2011) menyatakan bahwa umumnya kandungan oksigen 1-3 mg/L membuat aktivitas biota menjadi minimal. Konsentrasi yang baik disarankan lebih dari $3 \mathrm{mg} / \mathrm{L}$. Oksigen terlarut merupakan syarat penting yang harus dipenuhi untuk keperluan ikan dan invertebrata di perairan. Penelitian Talpur (2012) menunjukkan bahwa tingkat oksigen kurang dari 0,5 mg/L di dalam air tidak cukup untuk larva $P$. pelagicus dan menyebabkan kematian. Oksigen terlarut dipengaruhi oleh faktor lainnya, yaitu bahan organik, pH, suhu, dan salinitas (Nikhlani \& Sukarti, 2017). Verberk et al. 
(2016) menyatakan bahwa efek dari konsentrasi oksigen terlarut yang rendah akan berbahaya bagi organisme perairan apabila disekitar organisme memiliki suhu tinggi. Suhu di Perairan Batu Ampar tergolong kisaran normal, yaitu $28-29^{\circ} \mathrm{C}$. Hal ini membuat rajungan di lokasi penangkapan masih dapat mentoleransi konsentrasi oksigen terlarut yang tergolong minimal.

Nilai karbondioksida $\left(\mathrm{CO}_{2}\right)$ di Perairan Batu Ampar selama bulan Desember-Februari berkisar 3,93-4,21 mg/L. Penelitian Yani (2015) menemukan konsentrasi karbondioksida di Perairan Pantai Sorong berkisar 4,76-8,75 mg/L. $\quad \mathrm{CO}_{2}$ di perairan laut biasanya digunakan oleh tumbuhan dalam proses fotosintesis dan kalsium karbonat yang digunakan binatang laut untuk bahan pembentuk cangkang (Susana, 1988). Penelitian Agus (2015) menemukan bahwa terdapat pengaruh antara konsentrasi $\mathrm{CO}_{2}$ terhadap kemampuan molting kepiting.

Kualitas informasi analisis PCA dapat dijelaskan dari dua komponen nilai akar ciri (eigenvalue) (Honatta, 2010). Presentase variasi (\% variance) memberikan banyaknya informasi yang diperoleh pada masing-masing komponen (Soedibjo, 2008). Eigenvalue dari komponen utama pertama (sumbu $\mathrm{x}$ ) adalah 5,36 dapat memberi informasi sebesar $59,61 \%$ dari total parameter lingkungan. Eigenvalue komponen utama kedua melengkapi informasi yang tidak teranalisis oleh komponen utama pertama (Honatta, 2010). Eigenvalue dari komponen utama kedua (sumbu y) sebesar 2,03 dan dapat memberikan informasi sebesar 22,57\%. Komponen utama pertama dan kedua dapat memberikan informasi sebesar $82,18 \%$ dari data faktor lingkungan.

Diagram sebar menunjukkan titik dan garis hitam sebagai stasiun pengamatan dan parameter lingkungan yang diamati. Seluruh parameter lingkungan yang teramati direpresentasikan dengan vektor dan dijelaskan berdasarkan dua komponen utama (PC). Komponen utama (PC1) mempunyai korelasi positif terhadap 9 parameter yang diamati. Korelasi positif tertinggi pada PC1, yaitu DO terlarut. Berdasarkan hasil dapat diperoleh parameter kedalaman, kecerahan, salinitas, $\mathrm{pH}$ air, kecepatan arus air, kecepatan angin, suhu air, DO terlarut, $\mathrm{CO}_{2}$ memengaruhi kepadatan dan pola sebaran rajungan di setiap stasiun penangkapan.

Diagram sebar kuadran 1 (Stasiun Medan Seri dan Sungai Besar) menunjukkan bahwa lokasi penangkapan rajungan berkorelasi posistif dengan suhu air, kedalaman, $\mathrm{CO}_{2}$ bebas, dan $\mathrm{pH}$ air. Suhu air pada kedalaman yang dangkal cenderung sama. Hal ini sesuai dengan penelitian Sidabutar et al., (2019) bahwa fluktuasi suhu air permukaan dan dasar perairan disebabkan berkurangnya intensitas cahaya yang masuk. Kuadran 2 dan 3 tidak menunjukkan adanya parameter lingkungan yang berkorelasi. Hal ini disebabkan karena lokasi pengambilan sampel pada titik A1 dan A3 termasuk dangkal sehingga nilai parameter lingkungan tidak memengaruhi. Kuadran 4 pada diagram sebar menunjukkan parameter lingkungan yang berkorelasi positif terhadap lokasi penangkapan di Stasiun Padang Tikar. Parameter yang berkorelasi positif, yaitu salinitas, DO, kecepatan arus air, kecepatan angin, dan kecerahan. Nilai konsentrasi DO akan menurun seiring dengan peningkatan salinitas. Hal ini berdasarkan penelitian Sherwood et al. (1991) menemukan bahwa penurunan konsentrasi $\mathrm{O}_{2}$ selaras dengan kenaikan salinitas, namun efek ini berkurang ketika suhu air tinggi. Kecerahan air merupakan kemampuan intensitas cahaya matahari masuk ke dalam air, nilai kecerahan dapat memengaruhi nilai konsentrasi DO.

\section{KESIMPULAN DAN SARAN}

Kesimpulan yang diperoleh dari hasil kajian mengenai Kepadatan dan Pola Sebaran Rajungan (Portunus pelagicus) di Perairan Kecamatan Batu Ampar Kabupaten Kubu Raya, yaitu kepadatan rajungan berkisar 222-2581 ind $/ \mathrm{km}^{2}$ dan berbeda selama bulan Desember-Februari. Pola Sebaran 
pada bulan Desember dan Januari termasuk seragam dan mengelompok, bulan Februari memiliki sebaran seragam dan acak. Stasiun penelitian tidak berpengaruh terhadap kepadatan rajungan, sedangkan waktu penelitian di Pesisir Batu Ampar memberikan pengaruh. Kepadatan populasi rajungan dan pola sebaran rajungan berkorelasi positif terhadap kedalaman, kecerahan, salinitas, $\mathrm{pH}$ air, kecepatan arus air, kecepatan angin, suhu air, $\mathrm{DO}$, dan $\mathrm{CO}_{2}$ bebas.

Penelitian selanjutnya disarankan untuk mengetahui musim pemijahan rajungan di Perairan Batu Ampar, Kabupaten Kubu Raya sehingga pengelolaan rajungan berkelanjutan dapat terlaksana dengan baik dan tepat.

\section{UCAPAN TERIMA KASIH}

Ucapan terima kasih kami sampaikan kepada Nelayan di Kecamatan Batu Ampar, Desa Padang Tikar khususnya Bang Mus, Po'su Awi, Pak Hatta dan Fakultas Matematika dan Ilmu Pengetahuan Alam, Universitas Tanjungpura serta seluruh rekan atas bantuan dan kerja sama selama pelaksanaan penelitian.

\section{DAFTAR PUSTAKA}

Agus, M. (2015). Uji Sensifitas Kepiting Terhadap Perubahan $\mathrm{CO}_{2}$ Terlarut Dalam Media Terhadap Kemampuan Molting dan Mortalitas. PROSIDING Seminar Nasional Pangan, Energi, Dan Lingkungan 2015, 90, 111-118.

Metananda, A. A., Zuhud, E.A., \& Hikmat, A. (2015). Populasi, Sebaran, dan Asosiasi Kepuh (Sterculia foetida L.) di Kabupaten Sumbawa Nusantara Tenggara Barat. Media Konservasi, 20 (3), 277287.

Bambang, S., Karsono, W., Duranta, K., \& Prihatiningsih. (2011). Sumber Daya Ikan di Perairan Teluk Jakarta dan Alternatif Pengelolaannya (Issue Desember). PT. Penerbit IPB Press.

BPS. (2020). Kabupaten Kubu Raya Dalam Angka 2019. Badan Pusat Statistik, 366.

Castro, P., \& Huber, M. E. (2016). Marine Biology. In NASPA Journal (10th Edition, Vol. 42, Issue 4). McGraw-Hill Education. https://doi.org/10.1017/CBO9781107415324.004

Chande, A. I., \& Mgaya, Y. D. (2004). Food Habits of the Blue Swimming Crab Portunus pelagicu Along the Coast of Dar es Salaam, Tanzania. Western Indian Ocean J. Mar. Sci, 3(1), 37-42.

Donato, D. C., Kauffman, J. B., Murdiyarso, D., Kurnianto, S., \& Stidham, M. (2012). Mangrove adalah Salah Satu Hutan Terkaya Karbon di Kawasan Tropis. Brief, 12.

Erlinda, S., Sara, L., \& Irawati, N. (2016). Makanan Rajungan (Portunus pelagicus) di Perairan Lakara Kabupaten Konawe Selatan, Sulawesi Tenggara. Jurnal Manajemen Sumber Daya Perairan, 1(2), 131-140.

Ha, V. V., Nhan, T. H., Cuong, T. V., \& Doan., N. S. (2015). Stock and fishery assessment report of blue swimming crab Portunus pelagicus (Linnaeus, 1758) in Kien Giang waters, Viet Nam.

Hamsa, K. M. S. A. (1978). On the Meat Content of Portunus pelagicus with some Observations on Lunar Periodicity in Relation to Abundance, Weight and Moulting. Indian Journal of Fisheries, 25(1\&2), 165-170.

Hernowo, J. B. (2016). Birds Communities at Mangrove of Batu Ampar, Kubu Raya District, West Kalimantan Province. Jurnal Manajemen Hutan Tropika, 138-148. https://doi.org/10.7226/jtfm.22.2.138

Honatta, L. (2010). Struktur Komunitas Makrozoobenthos di Danau Lido, Bogor, Jawa Barat. Institut Pertanian Bogor.

Jose, J. (2015). Life Cycle and Biology of Portunid Crabs. Crustacean Fisheries Division, 93-99.

Juwana, S. (1997). Tinjauan Tentang Perkembangan Penelitian Budidaya Rajungan (Portunus pelagicus). Oseana, XXII(4), 1-12.

Kembaren, D. D., \& Adi, S. (2018). Struktur Ukuran dan Biologi Populasi Rajungan (Portunus pelagicus 
Linnaeus, 1758) di Perairan Kepulauan Aru. Jurnal Penelitian Perikanan Indonesia, 24(1), 51-60.

Krebs, C. J. (2014). PART II: Spatial pattern in animal and plant populations. Chapter 6 Spatial patterns and indices of dispersion. Ecological Methodology, 233-274. http://www.zoology.ubc.ca/ krebs/downloads/krebs_chapter_06_2017.pdf

Lee, S. Y., Primavera, J. H., Dahdouh-guebas, F., Mckee, K., Bosire, J. O., Cannicci, S., Diele, K., Fromard, F., Koedam, N., Marchand, C., \& Mendelssohn, I. (2014). Ecological Role and Services of Tropical Mangrove Ecosystems: a reassessment. Global Ecology and Biogeography, 23, 726-743. https://doi.org/10.1111/geb.12155

Lino, W. D. (2013). Perbandingan Hasil Tangkapan Bubu Rajungan yang Dioperasikan Pada Siang dan Malam di Perairan Pantai Pare-Pare Sulawesi Selatan (Vol. 84) [Universitas Hasanuddin]. http://ir.obihiro.ac.jp/dspace/handle/10322/3933

Mawaluddin, Palupi, R. D., \& Halili. (2016). Komposisi Ukuran Kepiting Rajungan (Portunus pelagicus) Berdasarkan Fase Bulan di Perairan Lakara, Konawe Selatan, Sulawesi Tenggara. Jurnal Manajemen Sumber Daya Perairan, 1(3), 299-310.

Melville-smith, R., Cliff, M., \& Anderton, S. M. (1999). Catch, Effort and the Conversion From Gill Nets to Traps in the Peel-Harvey and Cockburn Sound Blue Swimmer Crab (Portunus pelagicus) Fisheries. Fisheries Research Report No 113. Fisheries Research, 113, 1-25.

Mustikasari, E., Ramdhan, M., Amry, S. N., Heriati, A., Kadarwati, U. R., Prihantono, J., \& Pryambodo, D. G. (2019). Characteristics Analysis of Small Islands Ccological Dimensions in Nunukan Regency, North Kalimantan. Jurnal Kelautan Nasional, 14(1), 47-57. http://ejournalbalitbang.kkp.go.id/index.php/jkn/article/download/7458/pdf

Neilirrohmah, M., Fitri, A. D. P., \& Sardiyatmo, S. (2019). Pemanfaatan Umpan Alternatif Limbah Kepala Udang dan Waktu Immersing Bubu Lipat Terhadap Hasil Tanngkapan Rajung (Portunus Pelagicus) di Perairan Karimun Jawa, Kabupaten Jepara. Indonesian Journal of Fisheries Science and Technology, 14(2), 91. https://doi.org/10.14710/ijfst.14.2.91-95

Nikhlani, A., \& Sukarti, K. (2017). Survival and Metamorphosis Rate of Swimming Crab Portunus pelagicus Larvae With The Use of Phytoecdysteroid in The Artificial Feed. Jurnal Akuakultur Indonesia, 16(2), 261. https://doi.org/10.19027/jai.16.2.261-267

Nugraheni, D. I., Fahrudin, A., \& Yonvitner. (2015). Variasi Ukuran Lebar Karapas dan Kelimpahan Rajungan (Portunus pelagicus Linnaeus) di Perairan Kabupaten Pati. Jurnal IImu Dan Teknologi Kelautan Tropis, 7(2), 493-510.

Qadhafi, M., Sari, T. E. Y., \& Usman. (2013). Pengaruh Parameter Fisika Terhadap Hasil Tangkapan Alat Tangkap Gill Net di Perairan Kelurahan Sumber Jaya Kecamatan Kampung Melayu Kota Bengkulu Provinsi Bengkulu. Jurnal Online Mahasiswa, 1, 1-7.

Radifa, M., Wardiatno, Y., Simanjuntak, C. P. ., \& Zairion, Z. (2020). Preferensi Habitat dan Distribusi Spasial Yuwana Rajungan (Portunus Pelagicus) di Perairan Pesisir Lampung Timur, Provinsi Lampung. Journal of Natural Resources and Environmental Management, 10(2), 183-197.

Rahimah, I., Siregar, V. P., \& Agus, S. B. (2019). Kesesuaian Daerah Penangkapan Rajungan (Portunus pelagicus) Menggunakan Analisis Spasial Parameter Lingkungan dan Hasil Tangkapan di Pulau Lancang. Marine Fisheries, 10(2), 165-176.

Salim, D., Yuliyanto, Y., \& Baharuddin, B. (2017). Karakteristik Parameter Oseanografi Fisika-Kimia Perairan Pulau Kerumputan Kabupaten Kotabaru Kalimantan Selatan. Jurnal Enggano, 2(2), 218228. https://doi.org/10.31186/jenggano.2.2.218-228

Santoso, D., Karnan, Japa, L., \& Raksun. (2016). Karakteristik Bioekologi Rajungan (Portunus pelagicus) di Perairan Dusun Ujung Lombok Timur. Jurnal Biologi Tropis, 16(2), 94-105.

Schaduw, J. N. (2018). Distribusi Dan Karakteristik Kualitas Perairan Ekosistem Mangrove Pulau Kecil Taman Nasional Bunaken. Majalah Geografi Indonesia, 32(1), 40. https://doi.org/10.22146/mgi.32204

Sherwood, J. E., Stagnitti, F., Kokkinn, M. J., \& Williams, W. D. (1991). Dissolved Oxygen Concentrations in Hypersaline Waters. Limnology and Oceanography, 36(2), 235-250. https://doi.org/10.4319/lo.1991.36.2.0235 
Sidabutar, E. A., Sartimbul, A., \& Handayani, M. (2019). Distribusi Suhu, Salinitas dan Oksigen Terlarut Terhadap Kedalaman di Perairan Teluk Prigi Kabupaten Trenggalek. Journal of Fisheries and Marine Research, 3(1), 46-52.

Soedibjo, B. S. (2008). Analisis Komponen Utama Dalam Kajian Ekologi. Oseana, 33(2), 45-53. www.oseanografi.lipi.go.id

Susana, T. (1988). Karbon Dioksida. Oseana, XIII(1), 1-11.

Suy, S. (2013). Coastal Community Fisheries Catch Monitoring in Cambodia. Regional Fisheries Livelihoods Programme for South and Southeast Asia, 3(May).

Talpur, A. D. (2012). Effects of Stress Tests on Larvae Of Blue Swimming Crab, Advances in Environmental Biology, 6(7), 1909-1915.

Tampubolon, A. (2017). Mangrove: Memelihara Bentang Kehidupan, Lahan dan Laut. Media Brief, 5, $1-4$.

Tanti, J. T. H. Y., \& Sulwartiwi, L. (2010). Teknik Pemeliharaan Benih Rajungan (Portunus pelagicus Linn.) di Balai Besar Pengembangan Budidaya Air Payau Jepara Kabupaten Jepara Propinsi Jawa Tengah. Jurnal IImiah Perikanan Dan Kelautan, 2(1), 51-54.

Tirtadanu, \& Suman, A. (2017). Aspek Biologi, Dinamika Populasi dan Tingkat Pemanfaatan Rajungan (Portunus pelagicus Linnaeus, 1758) di Perairan Kota Baru, Kalimantan Selatan. Jurnal Penelitian Perikanan Indonesia, 23(September), 205-214.

Verberk, W. C. E. P., Overgaard, J., Ern, R., Bayley, M., Wang, T., Boardman, L., \& Terblanche, J. S. (2016). Does Oxygen Limit Thermal Tolerance in Arthropods? A critical review of current evidence. Comparative Biochemistry and Physiology -Part A: Molecular and Integrative Physiology, 192, 64-78. https://doi.org/10.1016/j.cbpa.2015.10.020

Vorsatz, J. P. (2009). Ecological Role of Estuarine Brachyuran Crabs in Mangrove and Salt Marsh Estuaries, Eastern Cape, South Africa By. In Africa (Issue August).

Wilson, P. C. (2011). Water Quality Notes : pH 1. 1-8.

Wisha, U. J., Husrin, S., \& Prihantono, J. (2015). Hydrodynamics Banten Bay During Transitional Seasons (August-September). Ilmu Kelautan: Indonesian Journal of Marine Sciences, 20(2), 101. https://doi.org/10.14710/ik.ijms.20.2.101-112

Wiyono, E. S., \& Ihsan. (2015). The Dynamic of Landing Blue Swimming Crab (Portunus pelagicus) Catches in Pangkajene Kepulauan, South Sulawesi, Indonesia. International Journal of the Bioflux Society, 8(2), 134-141.

Yani, A. (2015). Analisa Kelayakan Parameter Kualitas Kimia Air di Perairan Pantai Sorong. Jurnal Airaha, 4(2).

Zairion, Z., Wardianto, Y., Fahrudin, A., \& Boer, M. (2015). Distribusi Spasio-Temporal Populasi Rajungan (Portunus pelagicus) Betina Mengerami Telur di Perairan Pesisir Lampung Timur. Bawal, 6(2), 95. https://doi.org/10.15578/bawal.6.2.2014.95-102 